\title{
UM BOCADO DE SEXO, POUCO GIZ, QUASE NADA DE APAGADOR E MUITAS PROVAS: CENAS ESCOLARES ENVOLVENDO QUESTÕES DE GÊNERO E SEXUALIDADE
}

\author{
Fernando Seffner \\ Universidade Federal do Rio Grande do Sul
}

\begin{abstract}
Resumo: O texto está centrado no relato e na análise de cenas escolares, fruto de etnografia em salas de aula do ensino fundamental e do ensino médio na cidade de Porto Alegre, onde questões de gênero e sexualidade estão implicadas. O roteiro de cenas selecionadas permite transitar entre temas que envolvem autonomia pedagógica da escola; aprendizagem científica e processos de socialização no ambiente escolar; educação pública laica; valorização da diversidade; estratégias de inclusão; políticas de equidade de gênero; qualidade das aprendizagens escolares; papel do professor como um adulto de referência; e especificidades da educação pública. Privilegiam-se atravessamentos de gênero e sexualidade com raça, classe social, pertencimento religioso, moralidades familiares e geração. Ao final, estabelecemos alguns princípios gerais para o trabalho com gênero e sexualidade na escola. Palavras-chave: cenas escolares; gênero; sexualidade.
\end{abstract}

\section{Professores e professoras contra a parede}

Numa sala de aula, quase tudo acontece de modo muito rápido. Mesmo com planejamento bem estruturado, estratégias pedagógicas de qualidade, recursos tecnológicos de ponta, professores bem formados, as situações de ensino acontecem num "contexto de incerteza". ' Dentre os muitos fatores geradores desse "contexto de incerteza", a atenção neste texto está voltada para certo "tipo" de assuntos imprevistos que "invadem" aulas, imiscuem-se nos diálogos do professor com a classe, ou que "acontecem" pelos

Copyright (C) 2011 by Revista Estudos Feministas.

${ }^{1}$ Miguel ZABALZA, 2003. 
cantos da escola, mas terminam por fazer sentir sua presença no meio das aulas. ${ }^{2} \mathrm{Em}$ especial, interessam-nos os imprevistos e os assuntos em que questões de gênero e sexualidade estão presentes, diretamente ou como atravessamentos, na forma de pedagogias do gênero e da sexualidade. ${ }^{3}$ Queremos pensar essas questões a partir da sala de aula, um pouco inspirados pela obra do Marquês de Sade ${ }^{4}$ Filosofia na alcova. ${ }^{5}$ Em Sade, não se trata de fazer uma filosofia da alcova, mas de um filosofar na alcova, levando para lá os filósofos.

Dito de outro modo, queremos estar na escola (sala de aula, corredores, banheiros, cantos do pátio, sala de professores) com algumas compreensões que temos acerca de gênero e sexualidade e queremos estabelecer conexões entre essas compreensões e as cenas narradas a seguir. Além das cenas, trazemos impressões colhidas em inúmeros cursos e demandas de professores, que buscam ativamente nosso grupo de pesquisa e a universidade ${ }^{6}$ para fazer formação nos temas da diversidade, da inclusão, da sexualidade e do gênero. As ansiedades que levam professores a buscar formação dizem muito de suas dificuldades em abordar esses temas que invadiram os ambientes escolares nos últimos anos. Muito se cobra da escola quanto a uma adequada condução das questões de gênero e sexualidade, mas em outros fóruns (família, religião, televisão, partidos políticos, poder judiciário etc.) esses temas são tratados segundo outros critérios, o que por vezes coloca professores em uma difícil situação. É bastante frequente que líderes políticos, religiosos, comunidades inteiras, cobrem da escola e dos professores modos "adequados" de lidar com temas de gênero e sexualidade. Mas é também bastante frequente que essas instituições queiram forçar a escola na direção de princípios morais muito particulares, pouco preocupados com as especificidades dos procedimentos pedagógicos escolares e da educação em espaços públicos, salientando que é da escola pública que aqui vamos nos ocupar. A maior inspiração para pensar esses temas vem das cenas colhidas em escolas. ${ }^{7}$ Vamos direto a elas, vamos pensar nelas. Segue a primeira.

\section{Ela "despertou" para o sexo ${ }^{8}$}

Cheguei à escola antes do meu estagiário e fui conversar com a professora regente da turma. Perguntei a ela como o estagiário estava se saindo ao dar as aulas. Ela me

\footnotetext{
${ }^{2}$ Fernando SEFFNER, 2009

${ }^{3}$ Guacira Lopes LOURO, 1999.

${ }^{4}$ Donatien Alphonse François de SADE, 2010.

${ }^{5}$ Obra do Marquês de Sade, lançada em 1795, em que se aborda a educação sexual de uma jovem. Estruturada em forma de diálogos, aborda estratégias eróticas em conexão com posturas ideológicas e filosóficas. Possui numerosas traduções para o português e está disponível para download em muitos locais da internet.

${ }^{6}$ Grupo de Estudos em Educação e Relações de Gênero - GEERGE, vinculado ao Programa de Pós-Graduação em Educação da Faculdade de Educação da Universidade Federal do Rio Grande do Sul. Ver mais informações em: <www.geerge.com>

7 As cenas narradas constituem parte de um diário de campo em que o pesquisador anota situações potencialmente boas para pensar questóes de gênero e sexualidade, quando de suas visitas de supervisão a alunos estagiários de licenciatura em História. Todas as cenas narradas aconteceram em escolas públicas de Porto Alegre. Ao longo do texto, não fiquei preocupado em marcar de modo taxativo o que é transcrição do diário de campo e o que é texto atual, pois tudo tem a mesma autoria. Mas há indícios suficientes no texto para permitir visualizar essa diferença, que não é de autoria, mas de momento e propósitos de escrita. $O$ diário de campo é uma escrita "a quente", feita no "calor da hora", em geral logo após o acontecido, depois das visitas às escolas. O presente texto foi produzido de modo mais tranquilo e tem a pretensão de ser mais "objetivo" e "racional" na abordagem do que foi visto e vivido.

${ }^{8}$ Esta cena foi registrada no diário de campo em outubro de 2008.
} 
contou que aparentemente tudo estava bem e de imediato disse que ele deveria cuidar é com "algumas gurias" daquela turma, sétimo ano do ensino fundamental. ${ }^{9} \mathrm{Em}$ especial uma delas. "A Juliene ${ }^{10}$ no começo do ano era um amor de guria, mas depois entrou a andar com uns guris da oitava série," e eu sei quando isso começou, foi no passeio que a escola fez para a EXPOINTER. ${ }^{12}$ Na hora de embarcar, aquele monte de crianças e vários ônibus na frente da escola, muitos alunos aproveitaram para se desgarrar de suas turmas e de suas professoras. E a Juliene entrou no ônibus das oitavas séries, e ali começaram os namoricos dela com os guris". Perguntei o que poderia ter acontecido na curta viagem da escola até a EXPOINTER e lembrei que provavelmente alguma professora da oitava série estava no ônibus também, controlando os alunos. A professora regente me disse que, "para essas coisas, é só a gente se descuidar, e elas já acordam para o sexo e depois passam a influenciar as outras gurias da turma".

Essa cena, coerente com milhares de outras narradas por professoras em cursos ou assistidas em escolas, revela o enorme incômodo que os temas da sexualidade trazem na educação escolar. A descoberta das possibilidades eróticas do corpo acontece durante os anos escolares, e na maior parte das vezes a escola desempenha um papel importante, por conta de ser um local de forte sociabilidade. ${ }^{13} \mathrm{Em}$ numerosas inserções em escolas, fica claro que, para os alunos frequentarem a escola, é ótimo, o que não é agradável é assistir às aulas. Numa mesma classe, temos uma mescla de alunos e alunas, alguns já mais "despertos" para os temas da sexualidade e outros nem tanto, tornando mais difícil lidar com o assunto. Abordar certos temas ligados à sexualidade e mesmo ao gênero diante de uma classe de alunos pode ser quase completa novidade para alguns e matéria de total conhecimento, quando não de experiência prática, para outros. Isso nos remete a uma grave questão: os conteúdos ligados a gênero e sexualidade devem ser dados para toda a classe de alunos ou teríamos que fazer uma separação? E como seria essa separação? Meninos de um lado e meninas de outro? De um lado, aqueles e aquelas que claramente já possuem um repertório de experiências no tema e, de outro lado, os que ainda não manifestam tamanho desembaraço? Não temos uma fórmula ideal para isso, o objetivo é apenas mostrar que as classes de alunos são bastante heterogêneas quanto aos temas do gênero e da sexualidade. Isso aponta para atividades de livre adesão, em que alunos e alunas inscrever-se-iam nelas por interesse pelo tema, e não por obrigação. Ou seja, buscariam se informar quando estivessem dispostos a isso. Mas a escola é tradicionalmente

\footnotetext{
" Na época em que a cena foi registrada, a turma era chamada de "sexta série" e a escola estava em regime de transição para o sistema de nove anos de ensino fundamental. Em todas as demais cenas do presente artigo, a anotação foi feita preservando a nomenclatura antiga, própria do ensino fundamental de oito anos, pois todas as escolas estavam em processo de transição e as turmas nas quais as cenas ocorreram eram ainda integrantes do ensino de oito anos.

${ }^{10}$ Todos os nomes de pessoas e referências das escolas foram modificados, preservando o anonimato de pessoas e instituições.

"Quando a cena foi registrada, essa era a série final do ensino fundamental, agregando, portanto, os alunos de maior idade na escola.

${ }^{12}$ Tradicional exposição de animais no Rio Grande do Sul, realizada anualmente no Parque de Exposições Assis Brasil, no município de Esteio, na Grande Porto Alegre. Mais informações em: < http:// www.expointer.rs.gov.br>.

${ }^{13}$ Interessantes considerações sobre as impressões de alunos acerca da sociabilidade na escola encontramse em Marion MICHALSKI, 2010. A pesquisa que resultou no livro, a partir de trabalho de conclusão da aluna em curso de Especialização em Ensino de Geografia e História da Faculdade de Educação da Universidade Federal do Rio Grande do Sul, possibilitou contrastar o tédio das aulas com o gosto por estar na escola. Dentre as respostas do instrumento de pesquisa, um aluno escreveu: "sugiro que tenhamos aulas de cinco minutos, e recreios de quatro horas, pois temos muito o que conversar com os colegas aqui, e do jeito que é não há tempo suficiente, as aulas atrapalham muito a nossa vida na escola".
} 
o reinado das obrigações. Temos talvez que pensar uma escola em que, ao lado de atividades obrigatórias, os alunos possam escolher tais ou quais outras atividades, conforme sua disposição, seu interesse, sua orientação familiar.

Questões mais complicadas ainda surgem quando enfrentamos o seguinte dilema: aquelas e aqueles que já "despertaram" para o sexo estarão mais prevenidos em relação às doenças sexualmente transmissíveis, à AIDS e à gravidez adolescente do que aqueles que manifestam certa "ingenuidade"? Abordar o tema da sexualidade significa estimular a prática do sexo? Ou significa estimular a prática do sexo com os cuidados da prevenção? Não falar nada sobre o tema protege os "inocentes"? Essas questões são de difícil resposta, e a escola se debate no eterno movimento entre reprimir ou estimular, movimento válido para qualquer tema, especialmente quando se envolvem gênero e sexualidade. Outra questão é a de que a educação em temas de gênero e sexualidade não é atribuição exclusiva da escola, está vinculada a questões morais familiares que podem variar amplamente de família para família. Qual o limite do que a escola pode exigir? A cena seguinte leva adiante essa questão, e a partir dela podemos pensar numa ordem moral dos espaços públicos diferente da ordem moral das famílias.

\section{Com que roupa eu vou? ${ }^{14}$}

Escola de ensino fundamental, turno da tarde, dia muito quente. Chego cedo, embora vá assistir à aula do estagiário apenas no segundo período. Mas quero conversar com a professora regente antes do início do turno. O alvoroço na sala dos professores é grande em torno de um episódio que naquele momento está se desenrolando na sala da direção, a poucos metros dali. Logo me informam dos detalhes. Uma menina da sétima série veio novamente à escola vestindo um short muito curto e uma blusinha mais curta ainda. Ela fez isso ontem, foi mandada para casa, hoje voltou com a mãe. A mãe diz que não tem problema, que ela autoriza a filha a se vestir assim e que assume a responsabilidade, a menina é madura. A diretora (a escola não possui orientadora educacional) argumenta que isso provoca alterações nos alunos, perturba a classe e as aulas, incomoda os professores, e que não pode permitir. A mãe argumenta que se a menina pode vestir assim para andar na rua, por que não pode vestir do mesmo modo para estar na escola? Lembrei-me de relato parecido, quando fui dar palestra numa escola particular, professores e direção se queixaram de alunas do ensino fundamental que exageravam no estilo "patricinha" - com muita maquiagem, blusas decotadas, jóias, vestidos curtos esvoaçantes, cabelos ajeitados - e que isso causava toda espécie de transtornos em sala de aula. Nos dois casos, a opinião unânime das professoras é de que elas estavam provocando os guris, e depois poderiam acontecer coisas, e a escola seria responsabilizada.

O que fazer? Por onde passa a melhor medida a tomar? Nossa saída é o uniforme escolar? Mas basta ler memórias de alunas de escola normal para saber que elas transformavam em segundos as severas saias e blusas dos uniformes em trajes mais provocantes, a partir de pequenas dobras, jeitos e puxões. Cobra-se da escola uma postura de "contenção" nas questões de sexualidade dos alunos, mas os programas de auditório, novelas, músicas, revistas, ambientes virtuais e literatura juvenil trazem constantemente provocações, o que torna difícil acertar a medida. Temos uma explosão de meninas divulgadas pela mídia como modelos e manequins, em trajes provocantes, menores de idade ou já maiores, mas nitidamente aparentando corpos quase que de criança. Se a escola busca regrar a vestimenta escolar, parece muitas vezes como local do "atraso",

${ }^{14}$ Cena registrada no diário de campo em abril de 2008.

564 Estudos Feministas, Florianópolis, 19(2): 561-588, maio-agosto/2011 
confirmando opinião corrente de que tudo muda menos os rituais escolares.

Mas acreditamos que a posição mais adequada é a escola efetivamente regrar questões ligadas a gênero e sexualidade, sem discriminação por orientação sexual, e enfrentar a possível pecha de conservadora, validando sua vocação de instituição pública que visa à formação científica e à sociabilidade em regime de igualdade. Isso é fácil de dizer, mas muito difícil de praticar. De todo modo, para cada espaço público há determinados modos de portar-se e vestir-se, pensemos numa praça pública e numa sala de audiências de um tribunal. No caso da escola não é diferente, ela é um espaço público, portanto deve acolher a diversidade, mas isso não impede que tenha regramentos claros em relação a roupas e comportamentos, visando demarcar suas funções. Ocorre que na hora de definir o regramento, muitas vezes a escola se vê presa no centro de um conjunto de pressões de grupos que não percebem ser ela um espaço público, querem a escola como simples aliada de princípios morais ou projetos políticos muito particulares, querem colonizar o espaço público com vieses privados, o que é especialmente válido para as confissões religiosas. Para muitos indivíduos e instituições privadas, o espaço público é visto como um lugar que não tem especificidade, nele se deve simplesmente fazer aquilo que essa pessoa ou essa instituição entende como válido ou importante e que em geral coincide com seu modo de ser e seus valores no espaço privado. Os princípios de acolhimento da diferença, de negociação entre interesses diversos, de construção de regimes de tolerância e aceitação da diversidade, em geral, não são valorizados e muito menos percebidos como importantes para caracterizar o espaço público, noção que entre nós é bastante esvaziada. Para muitos, o espaço público, e igualmente as instituições públicas, serve simplesmente para fazer aquilo que eu acho que deve ser feito. Isso nos leva à próxima cena, na qual é clara a tentativa dos pais em ter a escola como aliada em seu projeto pessoal para o futuro do filho.

\title{
Nosso filho está aqui para que a escola faça dele o que nós queremos e não conseguimos
}

\begin{abstract}
Aproveito um intervalo em visita de supervisão a estagiários, em escola na região central da cidade, e fico um pouco "à disposição" para as habituais conversas com professores e direção, que já conheço de visitas anteriores e que tem gosto em me contar fatos do cotidiano escolar. De imediato, a orientadora veio dizer que ontem eles receberam um novo aluno na quinta série, vindo de outra escola estadual próxima desta. Ela fez entrevista com o pai e a mãe e percebeu certo constrangimento ao perguntar por que eles haviam trocado o filho de escola, assim quase no meio do ano, sendo as duas escolas igualmente próximas do seu local de moradia. A mãe iniciou uma longa explicação, dizendo que achavam que o menino não estava sendo bem "conduzido" na outra escola e que aqui ele poderia ser mais bem "conduzido", mas as coisas não ficavam claras. A orientadora perguntou diretamente se o menino havia sofrido agressão, bullying, algo assim na outra escola. A mãe disse que não, que não era isso. O pai, que até aquele momento estava mudo, subitamente entrou na conversa: "o problema é que na outra escola tudo o que ele fazia as professoras e os colegas achavam uma maravilha, e incentivavam". A supervisora fez cara de espanto, e a mãe explicou que o guri gostava de pintar, fazer desenhos, cartazes, e tinha até organizado uma mostra de pintura e de panos bordados nos corredores da escola, e que as professoras estavam estimulando isso demais. O pai saiu novamente do seu mutismo e disse com toda clareza: "na outra escola tudo o que ele fazia elas incentivavam, o que a gente quer desta escola é que daqui até o final do
\end{abstract}

\footnotetext{
${ }^{15}$ Cena registrada no diário de campo em junho de 2009.
} 
ano esse guri esteja desenhando menos borboletas e jogando mais futebol". Vale dizer que a orientadora, depois dessa entrevista com os pais, falou com sua colega da outra escola, e esta lhe disse que o menino estava muito bem integrado por lá, em sua turma e na comunidade, era reconhecido como liderança, embora fosse, efetivamente, um menino muito diferente dos outros meninos, mas era por eles respeitado, e era adorado pelas professoras e alunas. Considerando as difíceis e sofridas trajetórias escolares de outros meninos, igualmente mais sensíveis (ou afeminados, como a orientadora me cochichou), a colega da outra escola achava que este menino era muito bem aceito por todos, e isso se refletia inclusive em seu desempenho escolar, que era bom em todas as matérias. Sua saída da escola tinha sido uma surpresa para todos, motivo de tristeza para o menino e de comentários de todos os colegas.

O que fazer num caso desse? As principais estratégias pedagógicas de professores, direção e orientadores estão ligadas a dois conjuntos de preocupações. O primeiro deles, em garantir, estimular, promover, propiciar que o aluno tenha um bom desempenho escolar, entenda-se, que a escola esteja propiciando o crescimento cognitivo, cultural e científico da criança. Para isso existem as disciplinas escolares, a disponibilidade de livros e biblioteca, o laboratório de informática, as visitas a museus e instituições culturais, os debates, as avaliações, as aulas, enfim. Por outro lado, a atenção dos docentes e da direção se volta para garantir, estimular, promover, propiciar que aquela criança encontre na escola boa acolhida e possa fazer seu processo de socialização e ampliação da rede de amizades. Isso envolve garantir um clima de não agressão e respeito; promover atividades como gincanas, festas juninas, passeios, atividades lúdicas, recreios com jogos; respeitar os diversos pertencimentos religiosos dos alunos; não criar constrangimentos, de modo que aquela criança encontre ali um ambiente em que possa construir amizades, que constituem igualmente um patrimônio de aprendizado.

Vista a questão por esse ângulo, o aluno objeto da narrativa anterior estava bem integrado em sua escola de origem. Mas sua trajetória não apontava para aquele ideal de masculinidade que é hegemônico em nossa sociedade, o que incomodava fortemente o pai. Ou seja, podemos pensar que, se o menino na outra escola estivesse indo muito mal nos estudos, tivesse brigas com colegas, fosse bagunceiro e preguiçoso, mas jogasse futebol e fosse muito namorador das meninas, talvez não tivesse passado pela cabeça dos pais trocá-lo de escola. Na medida em que o aluno não se encaixava nesse ideal de masculinidade hegemônica, a família desejava uma escola aliada ao projeto de levá-lo de volta ao caminho tido como "normal". Retornando ao diário de campo, no caso em questão, a orientadora, revelando bastante autonomia e compreensão das questões de gênero, me disse que havia deixado claro aos pais que a escola não podia ser tomada como aliada desse projeto por muitos motivos, mas especialmente pelo fato de que a escola não operava com a ideia de que meninos só pudessem ser felizes jogando futebol, meninos também podiam ser felizes desenhando borboletas. Muito me surpreendeu essa afirmação da orientadora, que revelou sensibilidade e manifestou a autonomia didática e pedagógica que toda escola pública deve exercer. ${ }^{16}$ Para dizer claramente: a educação escolar não é uma simples continuação da educação familiar e a professora não é uma tia, função meio parecida com a da mãe. A escola é espaço público, a professora é uma educadora e uma servidora pública, e nela os aprendizados e as regras de sociabilidade

\footnotetext{
${ }^{16} \mathrm{Na}$ mão contrária, colhendo depoimentos de alunos assumidamente gays sobre seu período de vivência escolar, um deles narrou que, na primeira série, em geral ficava na hora do recreio brincando com as gurias e que gostava disso, e elas gostavam dele. Não tinha interesse nas brincadeiras dos guris. Um dia, estando ele sentado com as gurias na caixa de areia, a professora, de modo intempestivo, Ihe pegou pelo braço, "arrastou-o" para o jogo dos guris e lhe disse claramente: "tens que aprender que teu lugar é aqui, e não lá".
}

566 Estudos Feministas, Florianópolis, 19(2): 561-588, maio-agosto/2011 
são governados pela lógica do acolhimento e da negociação da diversidade.

Pode parecer duro o que segue, mas certamente é verdadeiro: na família, aquela criança, menino ou menina, é UMA criança, é A criança, a nossa filhinha, o nosso filhinho, adorado, adorada, e sobre ele/a temos muitos projetos particulares de criação, muitos sonhos e desejos. Na escola, aquela criança é MAIS UMA criança, será tratada de modo igual a todas as outras, será acolhida em sua diversidade e diferença (dentro, obviamente, dos limites do regimento escolar, que regra os comportamentos aceitáveis naquele espaço) e experimentará talvez pela primeira vez certo grau de impessoalidade que o espaço público tem. Ou seja, quando vou a um guichê do serviço público solicitar algo, eu não devo ser bem atendido porque me reconhecem como sendo $O$ fulano de tal, amigo do funcionário que ali está. Devo ser bem atendido porque sou MAIS UM cidadão, igual a todos, e porque todos devem ser bem atendidos. A educação escolar NÃO É o somatório dos pequenos projetos que cada família lança sobre seus filhos, ela é uma política pública, tem regramento próprio, tem objetivos cognitivos e de socialização coerentes com a ética e a moralidade pública e o ordenamento jurídico do país, e de certa forma se impõe sobre a educação familiar, outra afirmação que reconhecemos ser forte, mas que é em nosso entendimento absolutamente correta. Mas o servidor público não é um ser impessoal, ele está carregado de valores e regras morais próprias, e nem se pode querer que seja diferente. As professoras são em geral de outra geração, mais velhas do que os alunos. Seus valores morais e éticos em matéria de relações humanas podem ser muito diferentes dos alunos. Nem por isso elas devem se achar menos preparadas para lidar com as novidades das gerações atuais, embora isso exija estudo e disposição. A próxima cena nos guia na abordagem dessa delicada questão.

\title{
Beijo na boca é coisa do passado. A moda agora é... é namorar pelado
}

\begin{abstract}
Turno da noite, muito frio. Estou encostado na parede de um longo e gélido corredor de uma grande escola de ensino médio da cidade, cercado por todos os lados de alunos que conversam alegremente, enquanto esperamos que a funcionária venha abrir a sala de aula; é o período após o recreio. Aparentemente, os alunos conversam entre si como se eu não estivesse ali. Depois de mais de vinte anos visitando escolas, sei bem que eles estão propositalmente abordando temas que visam de certo modo me provocar, ou me impressionar. Ou seja, eles sabem que estou ali e em parte estão falando para que eu escute. E eu escuto, aliás, adoro escutar isso tudo, eles nem sabem o quanto. Um rapaz alto, magro, cabelo e roupas bem estilosas comenta com outro: "a tia me pegou ontem para dar sermão e disse que me viram dando beijos na boca da Roberta na sala de aula". Outro rapaz riu e perguntou: "e o que tu disse prá tia?". Respondeu o rapaz "estiloso": "eu disse prá ela que beijo na boca já era, o meu negócio agora é namoro depravado, é isso que as gurias gostam, é por isso que elas correm atrás de mim". Todos os guris riram e foram unânimes em afirmar que com esse comentário o rapaz tinha "tombado" a tia. Alguém comentou: "será que ela conhece a música?". Era visível o prazer que experimentavam por ter não apenas "escandalizado" a orientadora, como também por estarem ali me "escandalizando" com aqueles comentários. A porta foi aberta, todos entraram na sala, a aula começou. O estagiário passou a falar da Reforma da Igreja, de Lutero, e, para meu gosto, exagerou
\end{abstract}

\footnotetext{
${ }_{17}$ Música do DJ Thiago, intitulada "Namorar pelado", também se encontra com o título de "Namoro pelado", do grupo Axé Bahia ou do MC Pelé. Letra completa disponível em qualquer sítio de cifras na web. Cena registrada no diário de campo em agosto de 2010.
} 
notavelmente na exposição dos "pecados", "desmandos" e "desregramentos morais" do clero católico da época, o que agradou sobremaneira os alunos, que riam muito. A palavra "depravado", que havia sido dita no corredor pelo aluno, em dado momento foi utilizada pelo estagiário em sua exposição. Na supervisão posterior com o estagiário, discutimos isso longamente, enfatizando um conjunto de questões que produz a chamada Reforma da Igreja, desfocando da exclusividade em fatores de ordem moral, que pode agradar a classe, mas não permite adequada avaliação do episódio histórico."

Para além de ensinar tal ou qual disciplina, de ser diretora ou orientadora, a professora ${ }^{19}$ é um adulto de referência para os alunos. Ela certamente não é a tia, nem a segunda mãe dos alunos. Ela é um adulto de referência e uma servidora pública, que deve ter estabilidade no emprego, de modo a exercer adequadamente sua autonomia didática e pedagógica. Situada fora do círculo familiar do aluno, ela precisa ser vista como um adulto educador, com quem o aluno pode conversar sobre tudo. E pode conversar de modo diverso do que conversaria com sua mãe, sua irmã, seu pai, o padre ou a namorada. Se efetivamente o aluno disse aquilo mesmo para a orientadora, isso foi bom para o diálogo educativo. Mesmo tendo sido feito com intenção de "escandalizar" a orientadora, propicia que ela discuta o tema, mostre sua posição, faça críticas e considerações sobre a posição manifestada pelo aluno. Mas a professora deve fazer isso pensando nos valores públicos, na ética pública, e não apenas em suas crenças pessoais, senão a coisa toma o conhecido ar de "sermão de mãe ou de tia", ou "sermão de padre", de onde provavelmente a expressão se originou.

Os motivos que podem (e em nosso entender devem) levar uma orientadora a criticar a expressão "namoro depravado" do aluno precisam estar ancorados numa visão de equidade de gênero, de relacionamento que preserva a saúde e o respeito ao outro, que se articula com a imagem pública do aluno e com seu futuro, que articula as noções de amizade, afeto e amor, vínculos de respeito. Tudo isso é muito difícil de ser feito, mas pode revelar para o aluno que aquela professora, embora não concorde com suas atitudes, é alguém com quem ele pode conversar. A ação pedagógica escolar, em termos de gênero e sexualidade, decididamente tem que abandonar o ar de "catecismo" que em geral tem, dando margem a "sermões", "condenações morais", "denúncias de abusos", e tomar o caminho do diálogo, reconhecendo inclusive que, se o aluno pensa assim, é também porque em nossa sociedade existem milhares de dispositivos pedagógicos, na mídia ${ }^{20}{ }^{20}$ a cultura popular, na música, que lhe mostram essas atitudes como boas alternativas de vida. No caso, a fala do aluno está em parte ancorada na letra da música que dá título a este item, composição de muito sucesso e ampla divulgação na mídia. Em particular para o caso dos alunos do ensino médio, a diretriz deve ser de tratar o aluno como um sujeito quase adulto, autônomo, e reconhecer seu direito de discordar de nós. O modo como os alunos "processam" o que sai na mídia pode ser também muito diverso. Vamos a uma última cena, antes das considerações finais.

\section{A tia pensou que a gente era gay casado com filho adotado ${ }^{21}$}

Manhã de verão, temperatura agradável. A visita de hoje foi numa escola não muito longe de casa, fui então a pé. Quando estou já no quarteirão da escola, há muitos

\footnotetext{
${ }^{18}$ Conforme SEFFNER, 2009.

${ }^{19}$ Ao longo do texto, como já deve ter ficado claro, alterna-se o uso dos termos "professor" e "professora", ajudando o leitor a não esquecer que, na grande maioria das vezes, são efetivamente professoras que constituem a maior parte do magistério público.

${ }^{20}$ Rosa Maria Bueno FISCHER, 2002.

${ }^{21}$ Cena registrada no diário de campo em maio de 2010.
}

568 Estudos Feministas, Florianópolis, 19(2): 561-588, maio-agosto/2011 
alunos se dirigindo para o portão, e me vejo caminhando logo atrás de dois adolescentes, magros, negros, bermudas e camisetas típicas, tênis naquele estilo "pão de fôrma", cabelos eriçados, tatuagens, andar arrastado. O mais surpreendente é que cada um deles carrega nos braços uma criança pequena, e a mochila escolar nas costas, e mais correntes, boné, faixa no braço, enfim, o kit completo. Fico logo atrás deles. Os dois vão conversando cheios de gíria, falando de festa e zorra no final de semana, ocupam toda a calçada de lado a lado, se eu quisesse passar por eles, teria que andar seguramente pelo meio da rua, eles nem dão bola para mais nada. As duas crianças pequenas, no colo de cada um, estão muito bem arrumadinhas, são duas meninas, bem quietinhas, uma delas mexe no brinco de um dos guris enquanto caminham. Fiquei logo imaginando se eles eram pais daquelas crianças, ou se eram irmãos. A vista dos dois com duas crianças, e mais o jeito malandro de caminhar, de fato captava a atenção. Vindo em direção contrária, na mesma calçada, cruza por eles e logo depois por mim uma senhora, ela fica olhando os dois de modo bastante evidente, um pouco espantada de ver dois adolescentes com dois bebês no colo. Depois que ela passa, estou bem atrás deles, escuto a conversa. Um diz: "a tia ficou nos olhando, achou que a gente era seqüestrador de bebês. Tráfico de bebês". Os dois caem na gargalhada. O outro respondeu: "pior, vai ver que a tia achou que a gente é um casal gay, que adotou duas crianças". Mais risos. Eles entram portão adentro na escola e vão levando as duas crianças para a área da cozinha e do refeitório. Voltam um minuto depois sem elas, na maior ginga, se juntam com uma turma de guris, ficam zoando no portão de entrada. Entro na sala dos professores e vou logo perguntando para as professoras que por ali estão quem são aqueles dois alunos. De imediato, elas identificam de quem estou falando e respondem praticamente todas ao mesmo tempo dizendo quase a mesma coisa: todo mundo pensa que eles são os pais daquelas crianças, porque aqui na escola tem mesmo uns guris que já são pais, e tem gravidez adolescente. Mas os dois são filhos das duas cozinheiras da escola, elas vêm muito cedo para fazer a merenda da chegada dos alunos, então eles trazem as crianças para elas, que são suas irmãs, e as duas guriazinhas ficam aqui pela escola o tempo todo, as mães não têm com quem deixar lá na vila onde moram. Vale dizer que isso aconteceu poucos dias depois da decisão do Supremo Tribunal de Justiça, O STJ, que concedeu a adoção de duas crianças para um casal de lésbicas na cidade de Bagé (RS), episódio que vem recebendo uma ampla cobertura da mídia.

A discussão da adoção de crianças por casais homossexuais, que frequentemente aparece em algum registro na mídia brasileira nos últimos anos, estava muito comentada naquele momento. Isso repercutiu nos dois adolescentes, que perceberam a possibilidade de a senhora diagnosticar sua situação de modo diverso do que eles normalmente eram tidos. A todo instante, fatos da vida social produzem modificações nas representações que os alunos têm de si e do mundo. Isso acontece de modo muito ágil, ainda mais nas culturas juvenis, adeptas da novidade e que se entendem a si mesmas como culturas de indivíduos em transição. Mas essa cena mostra que podemos ter impactos muito positivos dos episódios sociais sobre os alunos e que podem ser aproveitados para debate em sala de aula.

\section{O que é possível concluir disso tudo?}

Dadas a dispersão e a diversidade de cenas, não nos atrevemos a fazer conclusões válidas para todas as situações escolares, ainda mais em um país tão grande e tão complexo culturalmente. Mas alguns princípios gerais do trabalho na escola podem ser alinhados.

- Abordar temas relativos a gênero e sexualidade exige nas escolas a presença de professores com formação específica, feita geralmente na modalidade de formação continuada ou em serviço. Esses temas aparecem de modo imprevisto na sala de aula, e em princípio qualquer professor deve estar preparado para uma abordagem inicial. Mas 
um trabalho continuado deve ser feito por docentes com qualificação dispostos a enfrentar essas questões.

- A abordagem pedagógica de questões de gênero e sexualidade não deve ser confundida com uma ação pautada em valores religiosos. A escola pública brasileira é laica, não professa uma religião oficial e aborda esses temas a partir dos consensos educacionais, dos parâmetros curriculares, do que já foi definido em regimentos e políticas públicas. Escola não é lugar de proselitismo religioso. A escola deve respeitar os diferentes pertencimentos religiosos de alunos e professores, sem validar algum como se fosse mais importante ou melhor do que outro.

- A autonomia didática e pedagógica das escolas públicas serve para que definam programas e abordagens nos temas do gênero e da sexualidade, que não necessariamente precisam ser a continuidade da moral das famílias. Os programas e as abordagens se montam a partir do que está definido pelas políticas públicas e pela legislação do país. Por exemplo, a legislação brasileira não considera a homossexualidade como crime nem mesmo como doença. É pensando nisso que a escola deve abordar o tema, e não confundindo homossexualidade com a noção de pecado, própria de confissões religiosas, mas incompatível com as políticas públicas educacionais.

- No atual momento político, uma forte característica da escola pública brasileira é a noção de inclusão da diversidade. A universalização do ensino fundamental, e a ampliação do leque de identidades culturais que reivindicam direitos e visibilidade, decorrentes do ambiente democrático que vige no Brasil pelo menos nos últimos 25 anos, impacta positivamente a escola a acolher muitos sujeitos que estavam alijados do acesso e da permanência nela. Isso traz problemas grandes de gestão das diferenças, mas não é motivo para se pensar novamente na volta de uma escola marcada pela exclusão dos "diferentes". Todos têm direito à educação, mas todos devem aprender a conviver e se respeitar no espaço público escolar.

- A escola não é mais a única fonte de saber para a maioria dos temas. Mas isso não deve implicar seu desprestígio. Em algumas áreas, ela é ainda importante fonte de acesso a conhecimentos científicos e sociais. Em outras áreas, ela atua estabelecendo a mediação entre diferentes fontes de conhecimento acessadas pelos alunos. Mas ela não perdeu sua função nem o professor perdeu sua importância como adulto de referência para o diálogo e a construção do conhecimento científico da criança.

- Os alunos não são mais egressos de famílias homogêneas. Temos hoje na sociedade brasileira uma diversidade enorme de agregados familiares. Não é mais o caso de se falar em família, no singular, e sim em famílias, no plural, e valorizar os arranjos que suportam o cuidado familiar das crianças, respeitando suas diferentes moralidades.

- As competências escolares, notadamente saber ler, argumentar, escrever, selecionar ideias, compreender o ponto de vista do outro, implicam atitudes pessoais difíceis de obter. Nesse caminho, é imprescindível o trabalho de um professor, que é um adulto de referência, especialmente, para temas de sexualidade e do gênero. Ser adulto de referência não se confunde com ser mais um familiar (mãe, tia, irmão mais velho, tio), mas implica uma relação de amizade profunda e gosto pelo aprendizado do educando, ao estilo do que Paulo Freire muito tratou. Brincando com uma conhecida expressão brasileira, "educador não é parente". ${ }^{22}$

${ }^{22}$ No período logo anterior ao golpe militar de 1964, a possível candidatura de Leonel Brizola à Presidência da República poderia ser impedida pelo fato de ele ser cunhado de João Goulart (Jango), o presidente em exercício. Dessa forma, os brizolistas cunharam a expressão que ficou famosa: "Cunhado não é parente! Brizola presidente!". 
- Muitas são as características pessoais que podem ser mobilizadas para construção de estigmas que geram violência estrutural na escola (violência conhecida atualmente em geral como bullying): cor da pele, pertencimento religioso, identidade de gênero, orientação sexual, região de moradia ou de origem, deficiência física, geração, obesidade, classe social, modelo de arranjo familiar, beleza etc. A orientação sexual que foge do paradigma heterossexual hegemônico (em geral nomeada como homossexualidade, mas que pode variar num amplo leque de possibilidades) aparece entre os motivos mais fortes de preconceito, o que gera agressão e violência simbólica. Pensamos que a abordagem dessa questão pode começar pela sexualidade, mas deve necessariamente envolver os temas de gênero, pois a excessiva fixação na sexualidade termina por trazer um caráter "exótico" aos indivíduos gays ou lésbicas, vistos como portadores de uma espécie de "sinal de nascença", quando em verdade é a construção simbólica da sociedade que elege, a cada momento, o que vai ser considerado atributo masculino ou feminino, e isso já experimentou variações históricas consideráveis.

- Por um lado, é gratificante perceber que tem havido muita procura dos professores e das professoras por formação na área de sexualidade e do gênero. Claramente isso demonstra que muitos educadores percebem essas questões e se preocupam com elas e com a violência escolar delas derivada. Entretanto, o desejo de entender mais da questão, e de fazer algo na escola, está por vezes animado de uma prática bem-intencionada, mas que é pouco fundamentada. Em outras palavras, suas intenções são boas, querem proteger quem sofre com a discriminação, mas são ações que se podem caracterizar como benemerentes, movidas pela compaixão. Em geral, revelam um lado maternal próprio do magistério feminino, que se incomoda com as agressões sofridas por meninos afeminados, mas se mobiliza menos para proteger meninas masculinizadas. É louvável a intenção dessas professoras em proteger esses sujeitos das agressões escolares, mas é certo que as ações só terão consequências educacionais duradouras e efetivas se estiverem estruturadas menos em cima de atos de caridade e mais em cima de princípios de equidade de gênero e de orientação sexual. Temos que evoluir das práticas de cunho caritativo para as práticas baseadas em princípios de equidade de gênero, que tratem do tema da abjeção, que enfrentem os processos sociais que produzem as normas de gênero, as normas que regem as construções corporais, exaltando alguns e condenando outros a zonas de exclusão.

Por fim, convém não perder de vista que a escola tem duas grandes tarefas, a saber: a alfabetização científica e a socialização das crianças e dos adolescentes. As políticas de promoção da diversidade sexual e da equidade de gênero não são políticas para minorias na escola. Em outras palavras, elas não são feitas "apenas" para os meninos afeminados ou mais sensíveis, "apenas" para as meninas que gostam de outras meninas, "apenas" para os meninos e as meninas que optam por modos transexuais. Existe uma vinculação clara entre o respeito à diferença sexual e de gênero e a qualidade das aprendizagens escolares. Políticas de equidade promovem um ambiente escolar mais sadio para todos e todas, diminuindo preconceitos e situações de baixa autoestima que potencialmente podem afetar qualquer aluno, pois todos nós temos atributos pessoais que podem nos tornar alvo de estigma, gerando tensão social, que diminui as chances de rendimento escolar.

\section{Referências bibliográficas}

EXPOINTER. Exposição Internacional de Animais, Máquinas, Implementos e Produtos Agropecuários. Disponível em: <http://www.expointer.rs.gov.br>. Acesso em: 20 fev. 2011 
FISCHER, Rosa Maria Bueno. "O dispositivo pedagógico da mídia: modos de educar na (e pela) TV". Educação e Pesquisa, São Paulo, v. 28, n. 1, p. 151-162, jan./jun. 2002.

GRUPO DE ESTUDOS EM EDUCAÇÃO E RELAÇÕES DE GÊNERO. Disponível em: <www.geerge.com>. Acesso em: 20 fev. 2011.

LOURO, Guacira Lopes. "Pedagogias da sexualidade". In: O corpo educado: pedagogias da sexualidade. Belo Horizonte: Autêntica, 1999. p. 7-34.

MICHALSKI, Marion. Identidade do aluno Juliano: liberdade e diversidade no ensino médio. Porto Alegre: Colégio Estadual Júlio de Castilhos, 2010.

SADE, Donatien Alphonse François de (Marquês de Sade). A Filosofia na alcova. São Paulo: lluminuras, 2010.

SEFFNER, Fernando. "Saberes da docência, saberes da disciplina e muitos imprevistos: atravessamentos no território do ensino de História". In: BARROSO, Véra Lúcia Maciel et. al. (Org.). Ensino de História: desafios contemporâneos. Porto Alegre: EST/ANPUHRS, 2010. p. 213-230.

. Da Reforma à Contra-Reforma: o cristianismo em crise. São Paulo: Saraiva, 2009.

ZABALZA, Miguel. "Os dilemas práticos dos professores". Revista Pátio, Rio Grande do Sul, v. 7, n. 27, p. 8-11, ago./out. 2003. Disponível em: <www.revistapatio.com.br>. Acesso em: 11 abr. 2011.

[Recebido em 15 de março de 2011 e aceito para publicação em 10 de maio de 2011]

\begin{abstract}
A Lot of Sex, a Little Chalk, Almost no Eraser and Many Tests: School Scenes Involving Gender and Sexuality

Abstract: The text focuses on reporting and analyzing school scenes, as a result of ethnography in elementary and middle school classrooms in Porto Alegre, Brazil. In these scenes questions of gender and sexuality are involved. The scenes selected deal with issues involving the school's educational autonomy; scientific learning and socialization processes in the school environment; secular public education; appreciation of diversity; inclusion strategies; policies of gender equity; quality of school learning; role of the teacher as an adult reference; specificities of public education. Preference is given to intersections of gender and sexuality with race, social class, religion, morals and family generation. In the end, we establish some general principles for working with gender and sexuality in school.

Key Words: School Scenes; Gender; Sexuality.
\end{abstract}

